\title{
Power Play: A Game Illustrating Power Transition in Authoritarian Regimes
}

\author{
Susan Turner Haynes, Lipscomb University
}

ABSTRACT One of the most alarming trends of the past decade has been the rise in authoritarianism and the growing support of strongman politics among citizens of democratic regimes. College instructors have a unique opportunity to challenge such thinking at a time when many of their students are still forming their political beliefs. Using a game, instructors not only can show students the perils of authoritarianism, they also can potentially expand students' appreciation of democracy. This article describes a game suitable for this purpose. Students take on the role of workers, soldiers, and rulers in a military dictatorship to learn about the "guns-and-butter tradeoff" and authoritarian uncertainty.

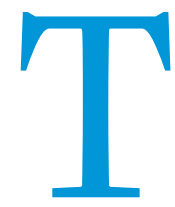

he "decline of democracy" has become an all-toofamiliar tagline, with Freedom House reporting a global loss in freedom every year since 2005 (Freedom House 2019). In explaining this trend, scholars often point to the corrosive effects of corruption and self-dealing on democratic ideals. When politicians leverage public trust for private gain with diminishing legal and political consequences, citizens begin to question government legitimacy and seek an alternate path forward (Rohac, Kumar, and Heinö 2017). Recent research reveals that this path is more likely to tend toward authoritarianism when a sizable portion of the electorate harbors specific ideological characteristics, such as favoring order and social cohesion (MacWilliams 2016). Economic dissatisfaction, brought on by an economic downturn and manifested in increased economic inequality and unemployment, is yet another trigger (Inglehart and Norris 2017).

The confluence of these factors has pushed us into what Edsall (2018) called an "Authoritarian Moment"-a time when an increasing number of citizens across the globe are willing to compromise democratic checks and balances for the sake of greater governmental efficiency. Many perceive strongmen as models to emulate rather than risky gambles to avoid. Policy prescriptions abound, but how can we address this issue in the classroom? I propose a game. This article introduces an original game designed to illustrate power distribution and transition in authoritarian regimes. I discuss the value of active learning and games in political science before addressing game objectives, game play, game iterations, and student feedback. I conclude with suggested questions for the game's debrief.

\section{ACTIVE LEARNING}

Research indicates that active-learning exercises can both increase knowledge retention (Levin-Banchik 2018) and optimize student

Susan Turner Haynes ${ }^{(\mathbb{D})}$ is assistant professor of political science at Lipscomb

University in Nashville, Tennessee. She can be reached at sthaynes@lipscomb.edu. engagement (Prince 2004). Despite this evidence, the majority of political science instructors continue to rely on a combination of lectures, exams, and written work. This holds true even in the discipline's introductory-level courses, in which active learning has the additional benefit of attracting new majors (Shellman and Turan 2006). Among the subfields, introductory courses in comparative politics are less likely than introductory international relations classes to include an active-learning component (Archer and Miller 2011). Research further indicates that although simulations have been more popular, games actually can be better at illustrating particularly abstract concepts (e.g., regime type) (McCarthy 2014). Games also can be more suitable for introductory-level classes, in which students may need additional motivation to learn (Bridge 2016). This article responds to such research by introducing a game designed for an introductory comparative politics class to illustrate several of the more complex concepts relating to authoritarianism.

\section{GAME OBJECTIVES}

Authoritarianism and democracy are key concepts in comparative politics, yet even the most sagacious students sometimes fail to fully discern the differences between the two. In particular, students can have difficulty understanding and differentiating between terms with which they are less familiar. This game provides students with a memorable experience that improves their understanding of concepts including clientelism, patronage, coup d'état, revolution, and populism. In addition to illustrating specific regime characteristics, the game underscores four broader themes of authoritarianism. First, authoritarian rule is sustained by a contingent of loyal actors rather than an autonomous dictator. Second, coalition loyalty is volatile, and a dictator's survival often depends on continual payment and favors. Third, toppling an authoritarian regime requires individual risk as well as coordinated collective action. Fourth, once a regime has been toppled, there is no guarantee regarding the benevolence or stability of the succeeding regime-even when leaders are legitimately elected, 
authoritarian backsliding remains a distinct possibility (Bizzarro and Mainwaring 2019). The game also indirectly provides a lesson about democracy, helping students to gain a better appreciation for political participation as well as the checks and balances built into established democratic systems.

\section{GAME PLAY}

The game is ideally suited for a class of approximately 10 to 20 students, with the classroom configured so that all students can see one another. The game can be played in as little as 10 minutes or it can occupy a 50-minute class period. It also can be played multiple times in the same semester, with the instructor incorporating new concepts into the game as students learn them. The flexible duration of the game is one of its main assets. The game takes place in 10 rounds; in each round, a student serves as either a dictator, a soldier, or a worker. Workers make the money and soldiers are paid by the taxes collected from workers. Soldiers' pay varies throughout the game and is decided by the dictator. Whereas both workers and soldiers may be dissatisfied with the present arrangement, the dictator cannot be voted out. Dissatisfied workers can only revolt and dissatisfied soldiers can only establish a coup. Both options, however, present risks. In the case of workers, a failed revolution means the elimination of their accumulated funds. In the case of soldiers, an unsuccessful coup means the elimination of funds as well as the additional consequence of automatic demotion. These are heavy penalties considering that the winner of the game is the one who accumulates the most money. The game's objective-as well as player roles-and action options and consequences are outlined in an instructional sheet provided to students either on the day of game play or in the previous class session (see appendix A). Some students are obviously disadvantaged in this regard, but it illustrates the power asymmetries inherent in authoritarian regimes. This disadvantage, coupled with the desire to win through financial gain, incentivizes workers to revolt and change their circumstances. Money is tabulated by the instructor on the whiteboard or by students on a separate sheet of paper. other students are doing. They may change their decision within the allotted time. If no card is played, the default is "defect" for a soldier and "work" for a worker. This should be explained to students at the outset to incentivize quick thinking. Students are allowed to talk with one another during the decision phase; however, most of the lobbying is done during the calculation phase, when the instructor assesses which cards were played and what this means for the next round. (Instructors are encouraged to do this out loud as they tabulate the money totals on the whiteboard or as students record the amounts.) The calculation phase can take a couple of minutes, depending on the cards played. More time may be allowed if fruitful conversations are occurring. Some students will make public appeals during this time while others talk quietly with their neighbors about what to do next.

When all students are situated and have the appropriate cards, the instructor reads the rules: each soldier can "suppress" up to three revolting workers and each worker produces $\$ 10$ worth of goods. In the first round, the dictator "taxes" all workers at $60 \%$, collecting $\$ 6$ per worker. The dictator then distributes approximately half of this amount among his soldiers and keeps the rest. (Diagrams showing ratios are available in appendix $B$ if an instructor wants to reference them or distribute them as handouts.)

Students are told that there are multiple scenarios that could result in a leadership change in the next round, including a successful coup, a democratic coup, or a fleeing dictator. A failed revolution or coup, however, will result in the dictator remaining in power. Because each soldier can suppress up to three workers, the rules heavily favor the status quo. If all soldiers remain loyal and suppress a burgeoning revolution, there is no way to oust the dictator. If all workers decide to revolt and at least one soldier defects, the regime can be toppled. It thus behooves the dictator to keep abreast of what is happening in each round because he can "flee" if he thinks his regime might be toppled. Fleeing allows the dictator to escape with his bank account intact.

With the numbers set up to favor the current regime, workers often are reserved in the first round, understanding that

\section{Dissatisfied workers can only revolt and dissatisfied soldiers can only establish a coup. Both options, however, present risks.}

The game begins with the instructor randomly selecting a dictator, who then selects approximately a quarter of the class to be soldiers. The soldiers relocate to sit near the dictator; remaining students are workers. Students are each given two action cards according to their role. The dictator has one card that states "rule" and another that states "flee." Soldiers each get a card that states "suppress" and another that states "defect." Workers each get a card that states "work" and another that states "revolt." Each action card is a different color. The instructor makes the cards before class, creating two cards for the dictator, enough soldier cards for a fourth of the class, and enough worker cards for three fourths of the class plus one.

Each round consists of two phases: a decision phase and a calculation phase. In the decision phase, students are given three seconds to choose one of two cards and place it in full view of the others. During this time, students are encouraged to look at what "revolt" is risky unless military defection can be expected. Two more rounds ensue. A failed revolution or coup is the most likely scenario in these rounds; however, if the status quo is disrupted via a coup, revolution, or power vacuum, the rules of the game change. The outcome of each scenario is detailed as follows:

FAILED REVOLUTION/COUP: Not enough workers revolt or soldiers defect to topple the regime. In the first few rounds, if all of the workers revolt and no soldier defects, the revolution fails due to the 1:3 ratio. Revolting workers then lose all of their money. If a soldier defects and an insufficient number of workers revolt, those who revolted lose their money, as does the soldier who defected. The soldier who defected also is demoted to worker, and the dictator selects a new soldier to replace him. 
COUP: Workers revolt and one soldier defects. If the necessary number of workers revolt and only one soldier defects, that soldier becomes the new dictator-regardless of the actions of the previous dictator. If the dictator did not flee, he loses his money and becomes a worker. If he fled, he keeps his money and becomes a worker for the next round. (The reincorporation of the dictator into the game makes it less likely for fleeing dictators to always win the game.) No election is held.

REVOLUTION: Workers overtake soldiers. If the necessary number of workers revolt in later rounds, the dictator is toppled and an election is held (i.e., determined by a show of hands.) Soldiers who chose to suppress now have zero points, as does the dictator if he did not flee. Neither suppressing soldiers nor the dictator are eligible for office, but they return in the next round as workers. The instructor asks which of the current workers would like to run for office and then allows 10 seconds for each candidate to explain why they should be the new ruler. Students running for office are allowed to make whatever promises they want. A vote is taken from current workers and the new ruler comes into office. The country then is effectively democratic-although in the game, as in reality, new leaders may adopt more authoritarian practices as they face greater challenges to power (Dresden and Howard 2016).

DEMOCRATIC COUP: Workers revolt and multiple soldiers defect. If the necessary number of workers revolt and more than one soldier defects, the dictator is toppled and the round ends with an election. The same rules apply as in a revolution, but there is the interesting possibility that the soldiers who defected, as well as outspoken workers, are eligible for office. Again, it is important to allow students to make whatever promises they want within 10 seconds. As in a revolution, the government established after a democratic coup is effectively democratic, although in the game, as in reality, a democracy established via a coup often is short-lived (Derpanopoulos et al. 2016).

POWER VACUUM: The leader flees and soldiers remain loyal. Regardless of the number of workers joining a revolution, if a leader flees, a power vacuum is created. In the rare case of a failed revolution with a fleeing dictator, soldiers are left to decide among themselves who will become the next dictator. Soldiers can make any promises they want to other soldiers, and they are not tied to those promises at the beginning of the next round when they come to power. The dictator keeps his bank account and returns in the next round as a worker.
When this is announced, the instructor allows time for all students to express their opinions and also encourages workers to solicit the help of soldiers and for the dictator to remind soldiers of their better economic situation. (In my experience, this occurs naturally.) This enables both sides to leverage and learn the power of propaganda.

It now becomes clear that if all but one worker revolts, workers can topple the regime. If soldiers understand this, they also realize that they should keep a keen eye on how many workers are revolting in the next round. The same is true of the dictator, who has the option to "flee." Students again are given three seconds to make a decision. In my experience, with the new rules, the regime is toppled within the next two rounds.

After a change in power, the new ruler must decide what to do with the soldiers who suppressed the revolt and the former dictator (if he did not flee). She may decide, for instance, to co-opt them back into her regime to mitigate the possibility that they will revolt in the next round, or she may punish them by making them workers. The new ruler also selects her soldiers. After these decisions are made and the students' seats are rearranged accordingly, the instructor informs students that a drought has occurred, cutting agricultural production in half (i.e., \$5). The new ruler must decide how much to extract and distribute, given the new situation. In most cases, this means a new leader cannot fulfill her campaign promises. In some cases, it becomes apparent that the student ruler never meant to do so in the first place. Both situations present opportunities for learning. The game continues for the remaining rounds with the drought impacting worker output. Each round presents an opportunity for a power transitionthe likelihood of which depends on student choices when playing the game. If a democratic transition occurs, the remaining rounds (which can be thought of in terms of years) are assumed to take place within the leader's legitimate term of office. Workers then have the option of enduring the drought under their newly elected leader (and theoretically waiting for the next legitimately elected leader to change their circumstances) or reverting to force to oust the leader.

\section{GAME ITERATIONS}

Several iterations of the game exist. First, the instructor can skew the election by counting incorrectly. For example, if a worker clearly wins against a soldier in an election, the instructor can announce the soldier's victory, to which students will immediately reply with confusion, followed by indignation on the realization of a rigged election and the understanding that their votes did not matter. This can demonstrate the difficulty in conducting fair elections. We also could ask students to submit votes via

\section{Students running for office are allowed to make whatever promises they want.}

If the status quo is maintained for three rounds, with the dictator and the military accumulating wealth and the workers enduring heavy taxes, the instructor informs students that the dictator now will reduce the number of soldiers. The dictator then chooses who he wants to "demote" to a worker. The instructor also informs the class that the dictator has increased taxes to $70 \%$ (i.e., $\$ 7$ per worker), and he will disperse approximately one quarter of the money among the soldiers and keep the rest. secret ballot. Even though this approach slows down the game, it has the benefit of capitalizing on player distrust-especially when it is introduced after instances of deception. It also can be used as a prelude to a larger discussion on how and why third parties are sometimes used to ensure electoral integrity.

Just as distrust is a critical concept, so is trust. In the original game, students are more likely to trust friends. We certainly can emphasize the importance of personal connections in developing 
trust; however, this does not illustrate the more nuanced reality of many authoritarian states, in which trust communities are developed on the basis of ethnicity. To reflect the reality of ethnic allegiance, an instructor could assign students to certain ethnic groups and emphasize Gurr's $(1970,87)$ point that "ethnicity is the obvious basis for mobilizing oppositions" in such situations. keep their money." This point was emphasized by students in all roles. A student who played the dictator, for instance, wrote "[i]n real dictatorships, there are no rules or best practices written down (or if there are, nobody obeys them). Dictators must feel their way through and figure out what will keep them alive for the most time."

\section{In addition to providing students with a better understanding of the difficulty of collective action, the game illustrates the pervasive uncertainty of authoritarian regimes and the cost of loyalty.}

International aid also presents an interesting learning opportunity. If the game plateaus after the drought, the instructor can announce that the United Nations is concerned about a humanitarian crisis and has extended aid. It is up to the instructor's discretion as to whether (1) the dictator chooses how the aid is spent, or (2) the instructor distributes the money to the military and the dictator to illustrate how international aid actually can embolden dictatorships by shifting the attention away from politics and onto economics (Hagmann and Reyntjens 2016). At the same time, however, an instructor can emphasize that such corruption may trigger greater international oversight and possibly increase the chances of foreign intervention.

A similar scenario can play out with the discovery of natural resources-wherein the country's leadership encounters substantial amounts of money and is not obligated to disperse the wealth across the country; this shows how such discoveries can entrench dictatorial regimes (Huntington 1991).

Finally, we could imagine how foreign intervention can change game dynamics. In one iteration, the instructor could pass a secret note to a soldier expressing that the soldier has US support. The soldier then could defect with the secret confidence that regardless of the numbers, she would topple the dictator. Or, perhaps the United States provides support to a revolution in the form of arms, changing the 1:3 suppression ratio presented at the beginning of the game. This illustrates that, historically, these events do not occur in a vacuum but rather have been abetted and sometimes even coordinated by outside powers (Weissman 2014).

\section{STUDENT FEEDBACK}

Students should be given time to discuss what they learned after playing the game. A brief written assignment also might be appropriate. I have employed both. Most recently, I asked students to provide written feedback. One student shared the following: "I have naively asked myself how people living under authoritarian regimes allow dictators to rule them without constantly revolting or demanding justice....[t]his game helped me learn that leaders and especially dictators can be extremely influential in keeping people in such a position as to make this extremely difficult." In addition to providing students with a better understanding of the difficulty of collective action, the game illustrates the pervasive uncertainty of authoritarian regimes and the cost of loyalty. A freshman, for example, wrote: "For me, [the game] gave me a good idea of how easily people's loyalties seem to fade.... It was interesting for me to watch people switch sides, depending on whether or not they thought it would let them
Students also learned from simulating elections. A few noted, for instance, that the elections were particularly "unfair," amounting to nothing more than "popularity contests"-yet, they also remarked that they could see how this reflected real life. (Similar remarks were made about the game as a whole.) "It was clear to me policy didn't really matter," stated one student; instead, "[i]t was about [candidates] convincing others that they were the right person for the job, and people rushing to believe it." Another student mentioned that votes seemed to be a matter of "personal loyalty" and "trading favors."

Apart from these themes, all students agreed that the game was enjoyable and they would play it again. One student even admitted that although she typically finds such games "corny," she found this one to be "intellectually stimulating, strategic, and incredibly fun to play." Furthermore, when end-of-course evaluations were submitted almost six weeks later, several students mentioned the game as the most fun and memorable activity of the class.

\section{CONCLUSION}

As with any classroom simulation or game, Power Play is an oversimplification of authoritarian rule and omits many of the nuanced dynamics. Coups take on many forms, for instance, and often require a dissatisfied coalition of elites and soldiers and do not always have popular support. More important, the original iteration of the game does not explore the full range of actions available to people serving in and under authoritarian regimes, and it fails to fully account for the ramifications of certain actions. Fortunately, we can address these shortcomings in the game's debrief. An instructor can use this time, for instance, to highlight the many different types of coups that exist. An instructor also can ask students, "What tactics other than violent suppression does an authoritarian state have at its disposal?" and "What other options are available to workers under an authoritarian regime?" An instructor also can ask for real-world examples. With more time, the instructor could ask students how the game might change if certain elements were introduced (e.g., rigged elections, foreign aid, and foreign intervention). The flexibility of the game means that an instructor could play the game again at several points throughout the semester, incorporating new elements, and students could have a different experience each time.

\section{SUPPLEMENTARY MATERIAL}

To view supplementary material for this article, please visit https://doi.org/10.1017/S104909651900129X 


\section{REFERENCES}

Archer, Candace, and Melissa K. Miller. 2011. "Prioritizing Active Learning: An Exploration of Gateway Courses in Political Science." PS: Political Science $\mathcal{E}$ Politics 44 (2): 429-34.

Bizzarro, Fernando, and Scott Mainwaring. 2019."The Fates of Third-Wave Democracies." Journal of Democracy 1: 99-113.

Bridge, Dave. 2016. "The Stag Hunt Game: An Example of an Excel-Based Probabilistic Game." Journal of Political Science Education 12 (2): 200-215

Derpanopoulos, George, Erica Frantz, Barbara Geddes, and Joseph Wright. 2016. "Are Coups Good for Democracy?" Research \& Politics 3 (4): 1-7.

Dresden, Jennifer Raymond, and Marc Morjé Howard. 2016. "Authoritarian Backsliding and the Concentration of Political Power." Democratization 23 (7): 1122-43.

Edsall, Thomas B. 2018. "The Contract with Authoritarianism." New York Times, April 5.

Freedom House. 2019. Freedom in the World 2019: Democracy in Retreat. Available at https://freedomhouse.org/report/freedom-world/freedom-world-2019/democracyin-retreat.

Gurr, Tedd R. 1970. Why Men Rebel. Princeton, NJ: Princeton University Press.

Hagmann, Tobias, and Filip Reyntjens (eds.). 2016. Authoritarianism and Aid in Africa. Chicago: University of Chicago Press.
Huntington, Samuel. 1991. The Third Wave: Democratization in the Late Twentieth Century. Norman: University of Oklahoma Press.

Inglehart, Ronald, and Pippa Norris. 2017. "Trump and the Populist Authoritarian Parties: The Silent Revolution in Reverse." Perspectives on Politics 15 (2): 443-54

Levin-Banchik, Luba. 2018. "Assessing Knowledge Retention, With and Without Simulations." Journal of Political Science Education 14 (3): 341-59.

MacWilliams, Matthew C. 2016. "Who Decides When the Party Doesn't? Authoritarian Voters and the Rise of Donald Trump." PS: Political Science $\mathcal{E}$ Politics 49 (4): 716-21.

McCarthy, Mary M. 2014. "The Role of Games and Simulations to Teach Abstract Concepts of Anarchy, Cooperation, and Conflict in World Politics." Journal of Political Science Education 10 (4): 400-413.

Prince, Michael. 2004. "Does Active Learning Work? A Review of the Research." Journal of Engineering Education 93: 223-31.

Rohac, Dalibor, Sahana Kumar, and Andreas Johansson Heinö. 2017. “The Wisdom of Demagogues: Institutions, Corruption and Support for Authoritarian Populists." Economic Affairs 37 (3): 382-96.

Shellman, Stephen M., and Kürsad Turan. 2006. "Do Simulations Enhance Student Learning? An Empirical Evaluation of an IR Simulation." Journal of Political Science Education 2: 19-32.

Weissman, Stephen R. 2014. "What Really Happened in the Congo: The CIA, the Murder of Lumumba, and the Rise of Mobutu." Foreign Affairs 93: 14-24. 

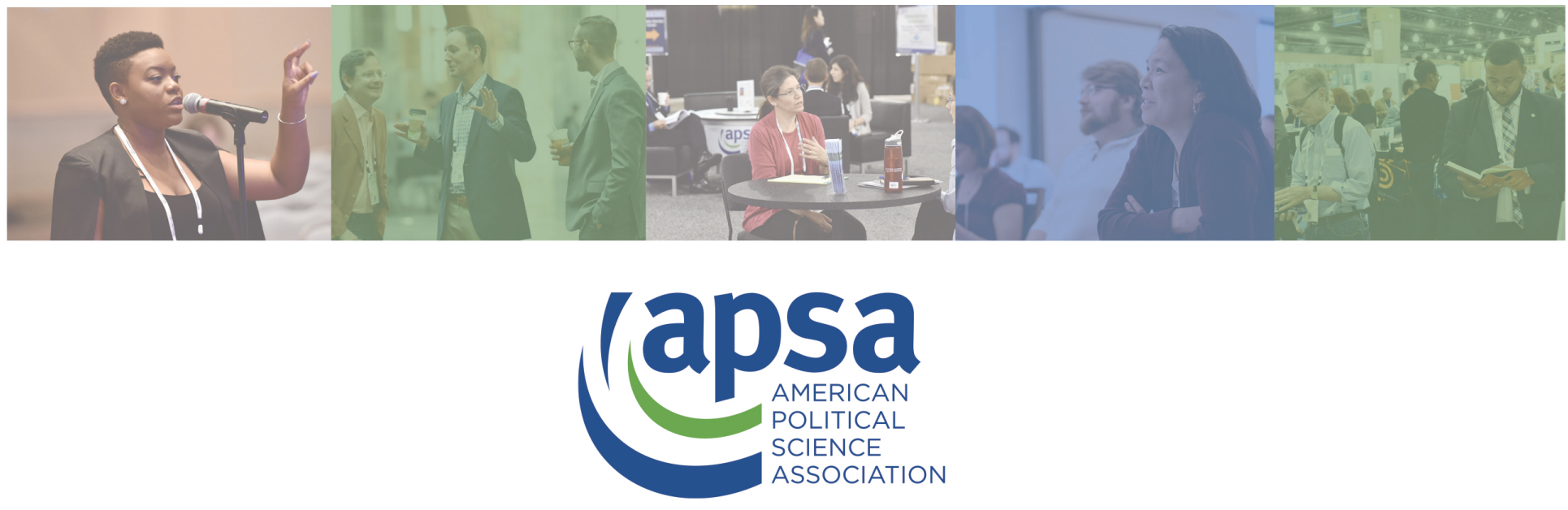

\section{Who Joins APSA?}

The American Political Science Association promotes scholarly research and discourse across the field, of political science, while continuing to promote, and expand professional opportunities. A membership in APSA enables access to benefits, programs, and services that will help you stay abreast with evolving methodologies, research topics, and approaches in the field and allow you to have a direct impact on the discipline.

APSA's member benefits are designed to ensure that all of our members receive the highest value for their membership. Our membership is comprised of:

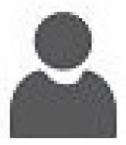

INDIVIDUAL MEMBERS:

Faculty, students, K-12 educators, consultants, researchers, retired members

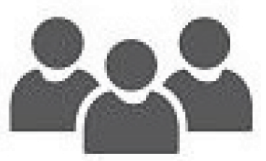

DEPARTMENTAL MEMBERS:

Undergraduate and Graduate Departments

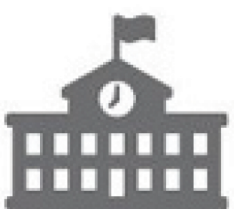

INSTITUTIONAL MEMBERS:

Libraries, research institutes, think tanks, embassies, and non-governmental organizations

\section{Go to www.apsanet.org to become a member today!}

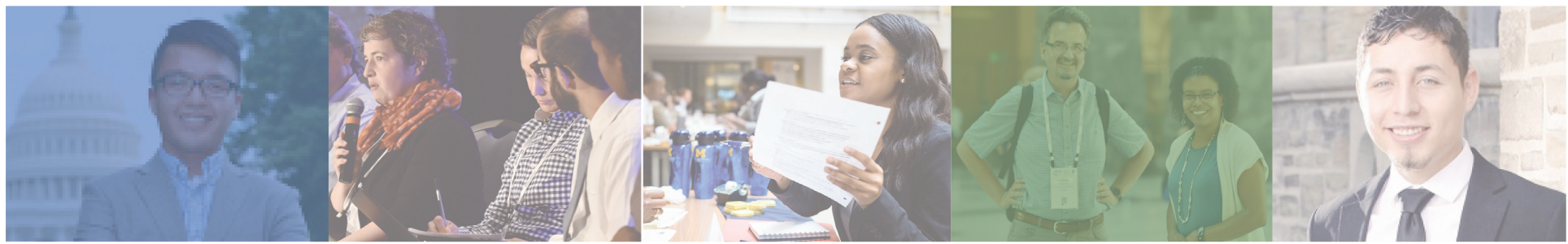

